\title{
Editorial: Questioning Assumptions
}

\section{Wim Vandekerckhove ${ }^{1}$}

Published online: 6 June 2019

(C) Springer Nature Switzerland AG 2019

One of the methods for doing philosophy of management is the philosophical questioning of concepts used by management scholars. What are the assumptions of the common notions through which we imagine and understand management today? Doing such questioning is not just fun (yes there is something geekish about us) but also progressive, innovative and political. If we alter those assumptions, what management becomes thinkable and possible? The articles in this issue of Philosophy of Management are examples of such endeavour.

In 'Towards a Political Philosophy of Management: Performativity \& Visibility in Management Practices', de Vaujany et al. (2019) question the assumptions of both immanent and transcendental understandings of organization. Is there an underlying realist structure to management or is it a speech-act? The authors use the Merleau-Pontian concepts of visibility and continuity to articulate a notion of performativity that goes beyond the immanence/transcendence dualism. They then reflect on the implications of performance and visibility for management scholarship. Everyday activity both performs and makes visible the world, and hence the organization. Thus, it is possible for us to ask (and action) the following: "What is the world of work and management we wish to constitute and make visible through our empirical and conceptual descriptions and what are the tools we use for this task?' (de Vaujany et al. 2019).

In 'Regaining the Soul Lost', Petrosyan (2019) questions the limits of depersonalization in management scholarship. On the one hand there are those who argue that the organization has to be depersonalized as much as possible. Maximization of effectiveness and efficiency requires the reduction of workers to their pure functionality. On the other hand, there are those who reject the alienated work practices and call for humaneness at and in work. Petrosyan (2019) argues the falsity of each position. Not in a prescriptive (and perhaps naive) attempt to create a middle ground, but rather in a negative analysis: those who strife for humaneness neglect the necessary reduction implied by any division of labour; those who want full depersonalization overlook the impossibility of it. The assumption of depersonalization implies the reduction of management to a technicality. Yet organization resists such a reduction. Management then is the coping with that residue. Hence, management appears

Wim Vandekerckhove

W.Vandekerckhove@greenwich.ac.uk

1 Faculty of Business, University of Greenwich, London SE10 9LS, UK 
as the attention for the personal and emotive in work and at work rather than the attempt to depersonalize.

In 'On Misunderstanding Heraclitus: the Justice of Organisation Structure', Shaw (2019) takes issue with how management scholars have been citing Heraclitus' stepping-into-theriver. It's not just the quote, of course. Shaw (2019) argues that understanding management and organization as process rather than things requires a careful awareness of the assumptions of that understanding. The author discusses the cosmology of Heraclitus to warn us about how a narrow conception of process can be blinding rather than enlightnening. Shaw (2019) writes that 'there is some uncertainty as to whether Heraclitus actually said that the universe was composed exclusively of processes rather than things, and even if that was what he thought, he intended his ideas on flux to be understood not in isolation but in the context of other aspects of his cosmology', such as justice and order. The article explores limits to process and flux, and provides a unity of opposites that keeps tensions in balance. Shaw (2019) argues for a 'balanced adoption of a range of different but complementary perspectives in studying organizations, rather than an exclusive or near-exclusive focus on our enterprises and institutions as arenas for constant and all-embracing processes of organizational change'.

In 'The Corporate Legitimacy Matrix - A Framework to Analyze Complex BusinessSociety Relations', Carson (2019) uses social contract theory and legitimacy theory to show how assumptions of managing complexity and social responsibility can be sketched along three dimensions. These three dimensions are: sustainability, stakeholders and trust. Carson (2019) explores these three dimensions of corporate legitimacy and how they are related. The article is not intended as a new model or a new ideal. Rather, the discussion in the article provides a better understanding of the relationship between CSR and corporate legitimacy, as well as a practical tool to manage actual corporate legitimacy challenges.

This issue closes with a combined book review on AI. Vandekerckhove (2019) discusses three books with very distinct questioning of assumptions about privacy, secrecy and existential threat: Henschke (2017) on personal information and virtual identities, Seele and Zapf (2017) on distinguishing privacy from secrecy, and Chamayou (2013/2015) on human interference with drone surveillance.

\section{References}

Carson, S.G. 2019. The corporate legitimacy matrix - A framework to analyze complex business-society relations. Philosophy of Management 18 (2). https://doi.org/10.1007/s40926-018-0099-9.

Chamayou, G. (2013/2015). Théorie du drone. La Fabrique Editions. English translation 2015, Drone theory (Penguin books UK), A theory of the drone (The New Press, USA).

de Vaujany, F.-X., J. Aroles, and P. Laniray. 2019. Towards a political philosophy of management: Performativity \& visibility in management practices. Philosophy of Management 18 (2). https://doi.org/10.1007/s40926018-0091-4.

Henschke, A. 2017. Ethics in an age of surveillance. Personal information and virtual identities. Cambridge: Cambridge University Press.

Petrosyan, A.E. 2019. Regaining the soul lost (the limits of depersonalization in organizational management). Philosophy of Management 18 (2). https://doi.org/10.1007/s40926-018-0092-3.

Seele, P., and C.L. Zapf. 2017. Die Rückseite der Cloud. Eine Theorie des Privaten ohne Geheimnis. Berlin: Springer. 
Shaw, D. 2019. On misunderstanding Heraclitus: The justice of organisation structure. Philosophy of Management 18 (2). https://doi.org/10.1007/s40926-018-0097-y.

Vandekerckhove, W. 2019. The business of algorithms. Philosophy of Management 18 (2). https://doi. org/10.1007/s40926-019-00111-2.

Publisher's Note Springer Nature remains neutral with regard to jurisdictional claims in published maps and institutional affiliations.

Wim Vandekerckhove holds a $\mathrm{PhD}$ in Moral Sciences from Ghent University. He is now Reader in Business Ethics at the University of Greenwich in London, where he is also co-Director of the Centre for Research in Employment and Work (CREW). 